\title{
THE OSTROWSKI TYPE INEQUALITIES WITH THE APPLICATION TO THE THREE POINT INTEGRAL FORMULA
}

\author{
SAnja Kovač, Josip PEČARIĆ AND SAnJA TIPURIĆ-SpuŽEVIĆ
}

Abstract. The generalization of the integral formula with three nodes is introduced, and some sharp and the best possible inequalities for the functions whose higher order derivatives belong to $L_{p}$ spaces are given. We establish non-weighted version of the three point integral formula. From the general non-weighted formula we shall get the famous Simpson, dual Simpson and Maclaurin formulae. Some new errors of approximation in these integral formulae are obtained.

Mathematics subject classification (2010): 26D15, 65D30, 65D32.

Keywords and phrases: sequences of harmonic polynomials, numerical integration, $L_{p}$ spaces, inequalities, Gaussian quadrature, Simpson's rule, dual Simpson's rule, Maclaurin's rule.

\section{REFERENCES}

[1] Lu. Dedić, M. Matić, J. PeČArić, On dual Euler-Simpson formulae, Bull. Belg. Math. Soc. 18 (2001), 479-504.

[2] LJ. Dedić, M. Matić, J. PeČARIĆ, Euler-Maclaurin formulae, Mathematical Inequalities and Applications 6, 2 2003, 247-275.

[3] P. J. Davis, P. Rabinowitz, Methods of numerical integration, Academic Press, New York-San Francisco-London, 1975.

[4] A. Guess AB, G. SCHMEISSER, Sharp integral inequalities of the Hermite-Hadamard type, Journal of Approximation Theory 115, 2 (2002), 260-288.

[5] S. Kovač, J. PeČArić, S. TIPURIĆ-SPUŽEvić, Weighted Ostrowski Type Inequalities with Application to Onepoint Integral Formula, Mediterranean Journal of Mathematics 11 (2014), 13-30.

[6] S. Kovač, J. PEČARIĆ, Weighted version of general integral formula, Mathematical Inequalities\& Applications, 13, 3 (2010), 579-599.

[7] S. Kovač, J. PeČARIĆ, Generalization of an Integral Formula of Guessab and Schmeisser, Banach Journal of Mathematical Analysis 5, 1 (2011), 1-18.

[8] S. Kovač, J. PEČARIĆ, Weighted version of general integral formula of the Euler type, to appear in Math. Inequal. Appl.

[9] S. KovaČ, J. PEČARIĆ, A. Vukelić, A generalization of general two-point formula with applications in numerical integration, Nonlinear Analysis: Theory, Methods \& Applications 68 (2008), $2445-2463$.

[10] Z. LiU, An inequality of Simpson type, Proceedings of the Royal Society A: Mathematical, Physical and Engineering Sciences 461 (2005), 2155-2158.

[11] D. S. Mitrinović, J. E. PeČArić, And A. M. Fink, Classical and New Inequalities in Analysis, Kluwer Academic Publishers, Dordrecht, 1993.

[12] M. NiezGodA, Grüss and Ostrowski Type Inequalities, Applied Mathematics and Computation 217 23 (2011), 9779-9789.

[13] J. PeČarić, S. VArošanec, Harmonic Polynomials and Generalization of Ostrowski Inequality with Applications in Numerical Integration, Nonlinear Analysis: Theory, Methods \& Applications 47 (2001), 2365-2374. 